\title{
Entomophily of Apple ecosystem in Kashmir valley, India: A review
}

\author{
Muzafar Riyaz $^{\mathrm{a}, \#}$, Pratheesh Mathew, ${ }^{\mathrm{a}, \#}$, Gabriel Paulraja, Savarimuthu Ignacimuthu, ${ }^{\mathrm{a}, *}$ \\ ${ }^{a}$ Entomology Research Institute, Loyola College, Chennai-34, Tamil Nadu, India. \\ *Corresponding author: eriloyola@hotmail.com Tel.: +9144-28178348 \\ ${ }^{\#}$ Authors contributed equally.
}

Available online at: www.isroset.org

Received: 04/Oct/2018, Accepted: 22/Oct/2018, Online: 31/Oct/2018

\begin{abstract}
Pollination is a prerequisite for the efficiency of the vast majority of the yields in agrarian and horticultural ecosystems. This is carried out mostly by insects which are the prime agents of pollination in flowering plants. The present article is a review of the pollination aspects of apple orchards of Kashmir. Apple inflorescence requires assistance from insects to carry out the process of pollination and hence more the number of pollinators, higher the chance for better crop yield. The most important role of pollination is played for the most part by the species of Hymenoptera in Apple ecosystems. The pollinators are declining steadily, because of habitat destruction and unrestrained use of agrochemicals, pesticides and other antifungal sprays. Necessary steps should be taken for a better understanding of diversity and bio-ecology of insects in agricultural fields such that the pests, pollinators and other beneficial insects could be monitored easily, which will further aid better and eco-friendly conservation and management tactics. Despite the fact that Kashmir is a leading apple producer in the country, productivity should be increased to meet future demand. New approaches are needed to increase apple production through sustainable ways including increasing insect pollinators that can be employed in apple orchards by farmers. Such a framework will enhance the economic growth from apple cultivation and furthermore conserve the natural pollinator species in Kashmir.
\end{abstract}

Keywords: Insect pollination, Bees, Hymenoptera, Diptera, Lepidoptera, Apple, Horticulture, Kashmir.

\section{INTRODUCTION}

Insects began to settle in the lower Devonian period [1] these are the presiding species in the Kingdom Animalia, because of their potential to withstand all kinds of climatic conditions. The first creatures among the animal kingdom to evolve flight were the Insects, some 400 million years ago. The flight was an instrumental part in the rise of a newly emerged class of insects which helped them to snatch a potential edge over others to adapt to most of the ecosystems of the earth. Insects are the most proliferous class of visible life form ever to colonize the planet [2]. The capacity to thrive in various conditions with differing versatile components helped these creatures to overcome even the extremes of natural conditions. The primary idiosyncrasy of insects to which their favorable outcome can be imputed must surely be that they have Arthropodic origin. On the contrary, the insects should be rated as highly successful creatures, because of their predominanc eand life within invertebrate phyla [3].

The acts played by insects might be considered in two noteworthy fields: the first is a trophic part which includes their roles in an ecological niche and the second is in the arena of shipment, as carriers of pollen and other plant items. Their central characteristic here is their portability in correlation with other small creatures. Nearly, in all terrene habitats, insects surpass and apparently counter balance every other creature [4]. Lamentably, in the human eyes, a portion of these insects happens to be pests of their crop yields. Man has advanced numerous strategies and procedures to control these pests which have made a negative impact on the natural ecosystem in unexpected ways. Enhanced pesticides usage, increased problems, thus it has renewed interest in biological control as a control measure by itself or as a part of integrated pest control system in agriculture sectors [5].

The present article is a review of pollination in the apple orchards of Kashmir with their biological and economic aspects. The impact of Apple cultivation on the economy of Kashmir along with biological perspectives like biological control, pollinatorhost plant interactions and role of pollination for better crop yield with its future scope are discussed here. 


\section{KASHMIR, A FRUIT ORCHARD}

Kashmir is tabbed as 'The Apple bowl of India [6] and apples of the region have acquired popularity among the people across the globe for their unique yet delicious taste. Kashmir is the prime source of total Apple production across the country. Apart from Kashmir, Apple is also grown in Himachal Pradesh and Uttarakhand. Apple cultivation has not only become a cash crop to the cultivators but has created a large number of job opportunities to the common man in the apple fields from the stage of planting to harvest.

Apple is the major crop of Kashmir, but the area is being used for cultivation of many other fruit crops as well, as per the data available at Directorate of Horticulture, Kashmir. The major fruit crops cultivated in the Valley are: Apple (Malus $\times$ domesticaBorkh), Pear (Pyruscommunis), Apricot (PrunusarmeniacaL.), Peach (Prunuspersica), Plum (Prunusdomestica L.), Cherry (Prunustomentosa), Grapes (VitisviniferaL.), Citrus (Citrus sinensisL. Osbeck. var. sinensis 'Malta'), Olive (Oleaeuropaea), Strawberry (Fragaria $\times$ ananassa), and some dry fruit crops like Walnut (Juglansregia), Almond (Prunusdulcis, syn. Prunusamygdalus) etc.

Though many fruit varieties have found place in the horticultural fields of Kashmir, apple still persists as the most important crop due to its demand in national and international markets.

\section{HORTICULTURAL PRACTICES IN KASHMIR}

Rice, the staple food crop of Kashmir that was cultivated from the time of first settlement was gradually replaced by cash crops, especially apple. The horticultural sector occupies a paramount position in the Valley [7] with a large area covered by different types of fresh as well as dry fruit crops. Horticultural crops hold around 20 percent area of the state. Around 50,000 million rupees are being generated annually by horticultural sector to the annual income of the state of Jammu and Kashmir [8]. Though most of the districts of Kashmir switched from rice to other horticultural cash crops like apple, the District Kulgam continued its rice cultivation attaining it the name "Rice bowl of Kashmir". The suitable climatic conditions and fertile soil are ideally beneficial for the cultivation of fruit crops in the Valley. Better alternatives for diversification and generating additional employment for the people are what horticultural sector has done since quite a while for the population of Kashmir [9] with more than 0.06 million families encompassing about 3.0 million people who are directly or indirectly linked with horticulture. An income of 65,000 million rupees has been generated during 2016-17 from fruit production [10]. The much better income gained from horticultural crops has transformed the agricultural fields of Kashmir in course of time and has encouraged even the new generation to opt for horticulture as a career. The production and productivity of fruit crops have shown a positive growth in Kashmir with an area of 144,992 hectares used for cultivation of fruit crops from the year 2001-2002 to 219,723 hectares in 2016-2017.

The growth in production and productivity of both fresh and dry fruits in Kashmir including Ladakh region for a period of 17 years from 2001 to 2017 is based on secondary data sources presented in Table 1. The data have been collected from the website of Directorate of Horticulture, Kashmir.

The total area covered by Apple is 45 percent, and it holds the supreme position among other cultivated fruits, but there are many other fruits cultivated in the area as well. Nearly 11.7 metric tons of apples were produced in Jammu and Kashmir in the year 2016, which accounts for 71\% of national production. The year 2017 was observed as the 'Year of Apple' in Kashmir. Apple orchards in Kashmir are one of the prime revenue generating fields for the fruit growers and farmers.

Table 1

Area and Production of Fruit crops in Kashmir from 2001-2016.

\begin{tabular}{lll}
\hline Year & $\begin{array}{l}\text { Area } \\
\text { (Hectares) }\end{array}$ & $\begin{array}{l}\text { Production } \\
\text { (MT. Tones) }\end{array}$ \\
\hline $2001-02$ & 144992 & 1017492 \\
$2002-03$ & 154181 & 1070045 \\
$2003-04$ & 162028 & 1173484 \\
$2004-05$ & 174906 & 1228694 \\
$2005-06$ & 179220 & 1294686 \\
$2006-07$ & 189614 & 1372600 \\
$2007-08$ & 191321 & 1495941 \\
$2008-09$ & 204800 & 1525618 \\
$2009-10$ & 211298.32 & 1571737 \\
$2010-11$ & 215305 & 2052311
\end{tabular}




$\begin{array}{lll}2011-12 & 221950 & 1980312 \\ 2012-13 & 230187 & 1572044 \\ 2013-14 & 233948 & 1782812 \\ 2014-15 & 237598 & 1355000 \\ 2015-16 & 218283 & 2212892 \\ 2016-17 & 219723 & 1960974\end{array}$

Source: Directorate of Horticulture, Kashmir

The following 12 districts including Leh and Kargil of Kashmir division are preoccupied with the cultivation of apple; the district Shopian attains the top position in having an area of 21,663hectares of land under major horticultural crops [9]. (Tables $2 \& 3)$

Table 2

Production of fruit crops in metric tons in Kashmir division for the year 2016-2017

\begin{tabular}{|c|c|c|c|c|c|c|c|c|c|c|c|c|c|c|}
\hline \multirow{2}{*}{$\begin{array}{l}\text { S } \\
\text { No }\end{array}$} & \multirow{2}{*}{$\begin{array}{l}\text { Type of } \\
\text { Fruit }\end{array}$} & \multicolumn{13}{|c|}{ Districts of Kashmir with their production in Metric tonnes/Mts } \\
\hline & & $\begin{array}{l}\text { Srinaga } \\
\mathbf{r}\end{array}$ & $\begin{array}{l}\text { Ganderb } \\
\text { al }\end{array}$ & $\begin{array}{l}\text { Budga } \\
\mathbf{m}\end{array}$ & $\begin{array}{l}\text { Baramull } \\
\text { a }\end{array}$ & $\begin{array}{l}\text { Bandipu } \\
\mathbf{r}\end{array}$ & $\begin{array}{l}\text { Kupwar } \\
\text { a }\end{array}$ & $\begin{array}{l}\text { Anantna } \\
\mathrm{g}\end{array}$ & $\begin{array}{l}\text { Kulga } \\
\mathbf{m}\end{array}$ & $\begin{array}{l}\text { Shopia } \\
\text { n }\end{array}$ & $\begin{array}{l}\text { Pulwam } \\
\text { a }\end{array}$ & Leh & $\begin{array}{l}\text { Kargi } \\
1\end{array}$ & Total \\
\hline & $\begin{array}{l}\text { (A)Fresh } \\
\text { Fruits }\end{array}$ & & & & & & & & & & & & & \\
\hline 1 & Apple & 17064 & 59768 & 132329 & 380005 & 64834 & 257072 & 188148 & 207259 & 237001 & 139288 & $\begin{array}{r}432 \\
7\end{array}$ & 1317 & $\begin{array}{r}168841 \\
3\end{array}$ \\
\hline 2 & Pear & 1782 & 3544 & 14045 & 9277 & 1261 & 3837 & 5048 & 7445 & 3177 & 8640 & 9 & 7 & 58072 \\
\hline 3 & Apricot & 31 & 506 & 106 & 431 & 85 & 357 & 752 & 460 & 62 & 900 & $\begin{array}{r}192 \\
3\end{array}$ & 3775 & 58072 \\
\hline 4 & Peach & 282 & 645 & 0 & 377 & 59 & 303 & 529 & 706 & 38 & 657 & 7 & 5 & 3609 \\
\hline 5 & Plum & 214 & 1611 & 1368 & 0 & 19 & 327 & 606 & 789 & 45 & 891 & 1 & 0 & 5872 \\
\hline 6 & Cherry & 1484 & 2372 & 0 & 1286 & 42 & 712 & 262 & 105 & 1453 & 558 & 2 & 6 & 8282 \\
\hline 7 & Grapes & 0 & 358 & 0 & 103 & 10 & 5 & 0 & 5 & 0 & 0 & 9 & 5 & 495 \\
\hline 8 & Citrus & 0 & 0 & 0 & 1 & 0 & 0 & 0 & 0 & 0 & 0 & 0 & 0 & 1 \\
\hline 9 & Olive & 0 & 0 & 0 & 1 & 0 & 190 & 0 & 0 & 0 & 0 & 0 & 0 & 191 \\
\hline 10 & Strawberry & 341 & 2 & 0 & 43 & 1 & 0 & 0 & 0 & 0 & 0 & 0 & 1 & 388 \\
\hline 11 & $\begin{array}{l}\text { Pomegranat } \\
\mathrm{e}\end{array}$ & 0 & 2 & 0 & 0 & 1 & 0 & 0 & 0 & 0 & 0 & 0 & 0 & 3 \\
\hline 12 & Other Fresh & 1180 & 771 & 731 & 156 & 2 & 1182 & 287 & 1136 & 288 & 117 & 0 & 0 & 5850 \\
\hline \multicolumn{2}{|c|}{ Total Fresh } & 22378 & 69580 & 148579 & 391680 & 66314 & 263958 & 195632 & 217905 & 242064 & 151051 & $\begin{array}{r}627 \\
9\end{array}$ & 5115 & $\begin{array}{r}178056 \\
2\end{array}$ \\
\hline \multicolumn{15}{|c|}{ (B) Dry Fruits } \\
\hline 1 & Walnut & 606 & 11155 & 14198 & 9956 & 2463 & 37423 & 41763 & 25259 & 12924 & 18184 & 109 & 12 & 174053 \\
\hline 2 & Almond & 58 & 19 & 1486 & 553 & 8 & 0 & 12 & 1 & 36 & 4180 & 1 & 1 & 6355 \\
\hline 3 & Other Dry & 0 & 0 & 0 & 1 & 0 & 3 & 1 & 0 & 0 & 0 & 0 & 0 & 5 \\
\hline \multicolumn{2}{|c|}{ Total Dry } & 664 & 11174 & 15684 & 10510 & 2471 & 37426 & 41776 & 25260 & 12960 & 22364 & 111 & 13 & 180413 \\
\hline \multicolumn{2}{|c|}{ Grand Total } & 23042 & 80754 & 164263 & 402190 & 68785 & 301411 & 237407 & 243165 & 255024 & 173415 & $\begin{array}{r}638 \\
9 \\
\end{array}$ & 5129 & $\begin{array}{r}196097 \\
5 \\
\end{array}$ \\
\hline
\end{tabular}

Source: Directorate of Horticulture, Kashmir 
Table 3

Total area (in hectares) under cultivation of different fruit crops in the division of Kashmir for the year 2016-17).

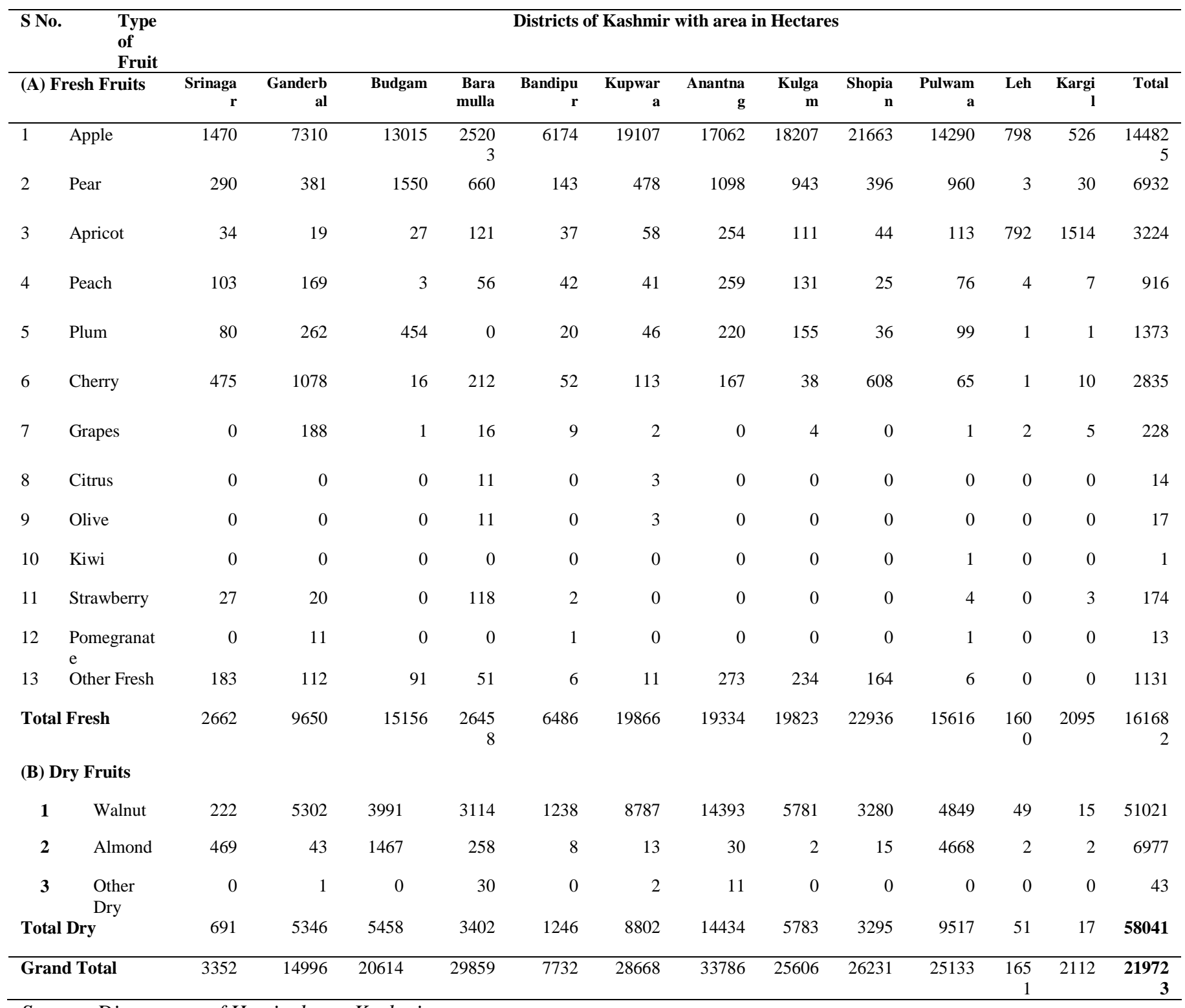

Source: Directorate of Horticulture, Kashmir

\section{APPLE, AN EMOLUMENT OF KASHMIR}

The apple is the member of sub-family Pomoideae of the family Rosaceae. The apple is considered to have emerged in the Caucasus mountain of South-Western Asia. Thereafter, the apple stretched out to all Europe and Asia during the pre-historic time and was fairly well entrenched at the beginning of Christian era [11]. Apple is considered as one of the most preferred healthy fruit by most of the international markets due to its nutritional value.

Apple cultivation in India dates back to the year of its introduction in 1865 at the Kullu valley of Himachal Pradesh by the British. Later, apple cultivation spread to the neighboring states due to its high economic value and favorable climatic conditions at these regions. Today apple cultivation has become one of the major crop varieties in the northern states of India. Kashmir has become one among the major producers of high grade apple varieties in India. The major apple producing states in India are Jammu and Kashmir, Himachal Pradesh and Uttarakhand. 
Though most of the districts of Kashmir produce and export apple, Shopian holds the major share of apple cultivation in Kashmir and is known as 'Apple town of Kashmir'. Increasing demand of apple from different parts of the country as well as from the international market has created a momentum for expanding the Kashmir land area under apple cultivation.

Horticultural sector is the backbone of the economy of Kashmir valley. The apples grow promptly right through temperate climate zones of the valley, where fertile soil, climate, slope, new techniques and favorable temperature add more boost to production of the fruit. Apple cultivation needs more care by farmers, compared to other crops like rice which was once the major crop of Kashmir. Throughout the year, the fruit growers and farmers are busy in maintaining the apple orchards by adding fertilizers to soil, spraying pesticides and then harvesting the fruit crop in the months from September to November. They bestow employment to about $60 \%$ of the population and are the foremost genesis of livelihood of many households, due to their good backward and forward linkages [12].

\section{POLLINATION AND PLANT-POLLINATOR INTERACTION}

Pollination is the term used to elucidate the transfer of pollen from the male part of the flower, the stamen, to the female part of the flower, the pistil. Pollination is carried out by means of natural agents like animals, water and air termed as pollinators. It is one of the most important processes when it comes to reproduction and is a crucial part of the ecosystem [13]. The mutualistic relation between floral and pollinator creatures has shown a beneficial outcome for both these life forms [14]. The evolution of angiosperms was shaped by the pollinators and vice versa by co-evolution. From way back, the relation between flowers and insects that deliver pollen grains to the female parts of plants, bespeak that they are key for the productivity of seeds and fruits [15]. Our perception of pollination as an important ecosystem task has enormously expanded.

A very good number of carrying agents are present in an ecosystem; they carry the pollen from one flower to another; bats, birds, insects, and wind are involved. They perform the role of dispersing pollens, spores, and seeds of many species of plants. Contrarily, most of the plants are dependent upon insects for their reproductive cycle by pollination to continue their race in enriching the biodiversity and a better yield [16].

The efficacy of pollination markedly hinged on some allocations and idiosyncrasies of pollinators such as sight, behavior, and learning ability etc., [17].The evolutions of the behavior of pollinators and flowering plants have become species specific in some cases that the elimination of one will drastically affect the survival of the other. The synergy between plants and pollinators has always been an exquisite arrangement to analyze and evolve new speculations in ecology and evolution [18]. The pollinators contribute enormous productive and ecological aid to flowering plants and mankind. The alliance between flowering angiosperms and their pollinators emerged about 225 years ago. Among 240,000 species of flowering plants, approximately 91 percent require the assistance of pollinators for the completion of their reproductive cycle [19]. Most of the flowering plant species in nearly all angiosperm groups examined hitherto have interactions with pollinators, $78 \%$ in temperate communities to $94 \%$ in tropical communities, which amount to more than $87 \%$ of all angiosperms [20]. As most of the agricultural crops are angiosperms, it does depend on the pollinator diversity for the expected yield. 35\% crops around the globe are depending on pollinators and entomophily is regarded as the key for pollination of around 70 to 108 major crops around the world [21]. Though the list of individuals of natural environment goes on which depends on pollinators, yet another big list shows the animals and plants that indirectly depend on pollinators and flowering plants being a member of the global food chain. Furthermore, studies reveal that over 300,000 species from Kingdom Animalia are directly depending on flowering plants [22].

For sustenance, visiting of flowers is a daily routine for most of the insects. The reward from floral creatures to anthophiles is a mixture of constituents of the three sugars, sucrose, fructose and glucose [23], mostly in an aqueous solution of nectar [24], as a propellant for aviation of anthophiles. Some insects are polyphagous while some others have become monophagous being species specific through evolution. Although lipid may be present [25] in nectar it may not play any important part. The flowers pollinated by Lepidoptera, hummingbirds and large bees are having the rich source of sucrose, while the pollination done to flowers by small bees, passerine birds and neotropical bats are rich in hexose [26]. Plant-pollinator interaction has evolved in such way that the presence of one cannot be replaced by another individual from the natural environment in most of the cases.

\section{INSECT POLLINATION IN APPLE ORCHARDS IN KASHMIR}

Studies have shown that apples are very much depending on anthophiles, especially animal pollinators. With the richness of native species, bees and other insects during the flowering period of a crop, there is an increase in fruit set [27]. It could be 
expected that more agents of apple pollination are present because of the presence of wide variety of natural pollinators in the nearby forest areas [28] which can be explored through comprehensive studies.

The average span of the apple blossom is about 9 days; usually it lasts from 15 to 20 days of first to the last blossom of the season depending upon the weather. Chilly weather at inflorescence period of apple will lengthen the period and hot climate will shorten it; besides parched blustery weather is also responsible for shortening the time period of blossom [29]. Different apple varieties have evolved different blooming seasons. Early blooming varieties are omitted by cultivators due to less chance of getting efficient pollinators at that time. The time of activity of pollinators and the blooming are very important for better fruit set. The introduction of crab apple trees in the apple orchards of Kashmir has enhanced the pollination rates. The blooming of crab apple trees and that of the main apple varieties is an important factor for better yield even if the abundance of pollinators is high at the orchards.

The horticultural sector in Kashmir has expanded its wings by using enhanced collection of manures and new approach of pest management to meet up with the stipulation of temperate fruit crops of the perpetually rising country population; in addition to this, more enhancement in pollination management is taken into consideration for the very needed growth of horticultural output [19].Exploring and studying the most efficient natural pollinators in apple orchards and enhancing their population in those areas will assure maximum productivity from apple trees as pollination is the pre-requisite for apple production from the biological perspective.

Pollination plays an important role in generating the commercial apple production in Kashmir [30]. Likewise, the agricultural and horticultural ecosystems in Kashmir are depending on pollinators to uphold the biological diversity of the region [31].A detailed study of the insect species involved in pollination will help to employ methods to conserve these species by providing favorable environments and also by preventing hazards on them through pesticide application.

During early spring of apple inflorescence, inhabitant insect pollinators were collected from different apple producing localities of Kashmir valley. [32] sampled Hymenopterans, Dipterans and, Lepidoptera visiting the flowers of apple; 17 species were associated with these three orders. Relative affluence in the visitation of apple bloom displayed that Hymenopterans attained the top position to visit apple flowers adding about $74.94 \%$ followed by Dipterans with $18.86 \%$; Lepidopterans with $3.38 \%$ and Coleopterans with 3.04\% [31]. Following are the species of different orders of insects sampled during 2013, which [31] has reported as pollinators in apple ecosystem as follows:

\section{Hymenoptera:}

ApismelliferaL., Apisceranaindica (F.), Euceravernalis(Morawitz), Anthophora confuse (Smith), Xylocopa fenestrate(F.), Bombusfunerarius(Smith), Thyreusnitidulus(Fabricius), Melissodesbimaculatanulle(Laberge), Lasioglossummoroi(Fabricius), Ceratinacalcarata(Robt), Ceratinahieroglyphica(Smith), Halictus confuses (Smith), Polistesmaculipennis(Saussure), Vespa auraria(Smith), Andrenagravida(Imhoff), Pisonpunctifrons(Shuckard), Athaliaproxima(Klug), Megascoliahaemorrhoidalis(F.), Eusaphygaverticalis(Cresson).

These 8 insects are identified up to genera level viz., Anthophorasp., Polistessp., Odynerussp., Pimplasp., Megachilesp., Osmiasp., Pepsis sp., Rhychiumsp.

\section{Diptera:}

Eristalissoliatus(Walker), Dideafasciata(Macquart), Scaevapyrastri(L.), Syrphusbalteatus(De Geer),Syrittorientalis(L.), Eristalistenax(L.), Eristalisarbustorum(L.), Sphaerophoriascripta(L.), Hermetiaillucens(L.), Helophilustrivittatus(F.), Bombylus major (L.), Muscadomestica(L.), Dryomyzaflaveola(Fabricius).

These 11 species are identified up to genera level Eristalinussp., Syrittasp., Sphaerophoriasp., Eristalissp., Bibiosp., Chrysomyiasp., Pseudopyrelliasp., Bombylidaesp., Machinussp., Fannasp., Sarcophagasp.

\section{Lepidoptera:}

Pierisbrassicae(L.), Cynthia cordui(Linn), Coliasromonovi(Gr. Gosh), 3 species of coleopteran viz.,Coccinellaseptumpunctata(L.), Hippodamiavariegata(Goeze), Alticacyanea(Weber).

\section{Coleoptera:}


Coccinellaseptumpunctata(L.), Hippodamiavariegata(Goeze), Alticacyanea(Weber).

\section{Odonata:}

Ischnurapumilio(Charpentier), Libellulaquadrimaculata(L.)

Besides, [5] also reported the pollinators in apple orchards of Kashmir valley, visiting for pollen and nectar as follows:

\section{Hymenoptera:}

Xylocopa valga, Xylocopa violacea, Bombus simillmus, Bombus tunicatus, Lassioglossom himalayense, Lassioglossom nursei, Sphecodes tantalus, Sphecodes lasimensis, Andrena patella, Andrena cineraria, Anthidium conciliatum.

\section{Diptera:}

Sphaerophoria bengalensis, Metasyrphus bucculatus, Episyrphus balteatus, Eristalodes paria, Eristalis tenax, Eoseristalis cerealis

\section{DOMINANT POLLINATORS IN APPLE ORCHARDS OF KASHMIR:}

For fruit, seed set and good outcome, the anthophiles bring assistance up to 75\% of crop species by pollination [33]. Kashmir being rich in biodiversity has large number of natural pollinators from which it could be expected that more number of unexplored apple pollinators are contributing in the pollination process. The honey bees are the species of family Apidae of the order Hymenoptera. The most interesting part about the species of honey bees is that they can easily be managed, and depending upon the required concentration, they can be placed in an orchard. The visiting time of bee on apple inflorescence during the day is mostly at 9 a.m. [34]. In this case, the apple growers can take honey bees as their apple pollinating operators, as pollen and nectar of apple are promptly collected by honeybees [35].

Studies have shown that there is more number of bee pollination than from any other family/order of class Insecta. Although insects from many orders are taking care of pollination, the dominant native pollinators of Kashmir are from the family Halictidae of the genus Lasioglossum [36]. The agents of pollination other than insects like wind, water, bats seem to have less contribution in the case of apple pollination due to the floral structures and location of flowers on higher branches of the plant. Most of the nectar and pollen feeding animals like insects and humming birds could possibly be the predominant pollinators of apple. Besides apple, there are many other selected crops in the region; nearly $80 \%$ pollination among them are carried out by honey bees [37].

Species from Hymenoptera and Lepidoptera are taxa usually considered as pollinators in agricultural and horticultural fields. Besides these, various species of non-syrphid Diptera are also providing pollination service but due to lack of consideration, they are ignored as anthophile [38].The absence of some birds, like humming birds, sun birds etc in Kashmir have eliminated the chances of bird pollination which could have been in the list of dominant pollinators of apple.

Many studies reveal that pollination of apples is carried out mostly by insects; this clearly opens a path to future studies related to the influence of services by insects as pollinators and identification of species which are most prime helping hands for the fruit growers, so they can properly be conserved and proper management can be taken into consideration [39].

A recent study revealed that anthophiles which are carrying out the work of pollination usually bees and other insects from class Insecta are diminishing at a startling rate by changes in the climate, altered foraging and development of colonies because of decrease in pollen and nectar output, which would cause a huge loss and threat to the very survival of floral life and it will also result in the downfall of many extensive crops. The decrease in the pollinator species will pose a major menace to both agricultural and horticultural crops in many parts of the globe, which in turn will result in a decrease in crop outcome. In the last 20 years, honeybees have been diminishing by $30 \%$ which has raised a big challenge to the agricultural sector [40]. The gradual decline in bee population is being reported from different countries and has become a global phenomenon. At this juncture the number of bee species present in apple orchards of Kashmir and factors that are detrimental to their survival need to be studied and documented for their conservation as well as for the better output of apple cultivation. As Kashmir is rich in 
fruit cultivation, there are various issues which can lead to even eradication of natural pollinators. A good number of insecticides, pesticides and chemicals are being sprayed in apple orchards which affect the pollinators [41].

\section{CONCLUSION AND FUTURE SCOPE}

The data recorded from different localities of Kashmir have clearly opened new avenues to explore insect diversity which can lead to even new conclusions, for conserving the biodiversity of pollinators in Kashmir valley. The honeybee diversity is dominant in agricultural and horticultural fields of Kashmir; besides species of Hymenoptera, Lepidoptera, Diptera and other groups of insects must be taken into consideration for preservation.

Since honey bees are the significant pollinators of apple, it is fitting to do apiculture alongside apple development in the apple plantations which will improve the pollination of apple trees and give a parallel wellspring of wage from nectar extraction in this way upgrading the aggregate financial yield of apple plantation of Kashmir. The increased presence of honey bees through apiculture will also enhance the very purpose of crab apple trees in the apple orchards.

The absence of bird pollinators in this area eliminated the chance of increased pollination but on the other hand, it has created a vacancy for other insect pollinators to take up; it has also decreased the degree of competition among pollinators in the apple orchards of Kashmir. The increased transformation of land area for apple cultivation will have a negative effect in the natural environment like any other cash crop cultivation. But apple being totally dependent on pollination is in need of insect diversity and has got a good role in the conservation of these insect species by providing forage and habitat for their survival.

The application of mixed fruit crop cultivation also enhances pollination by attracting pollinators as the floral characters that attract pollinators like color and size of the petals, amount of nectar and pollen etc vary from plant to plant. The probability of getting a less attractive plant pollinated by a pollinator gets increased by the presence of another plant in the neighborhood that can attract pollinators even from far distance by which one plant gets benefitted by the other. The practice of mixed crop is already being carried out in Kashmir like apple orchards with pear, plum, peach, cherry etc which will have a greater impact on economic gain from horticulture as well as on the conservation aspects.

The present review points to the demand for a far-reaching work in taxonomic arenas of local species of insects, both advantageous and harmful, which without a doubt, is required to screen the species of insects which have both gainful and vermin esteem and which will also help in the agricultural and horticultural biological ecosystems of the area. These conservation steps not only contribute to the better productivity of apple cultivation but also indirectly conserve the natural insect diversity of Kashmir.

\section{Conflict of interest}

The authors declare that there is no conflict of interests regarding the publication of this paper.

\section{Acknowledgement}

The authors wish to thank the Entomology Research Institute, Loyola College Chennai - 34, Tamil Nadu, India for extending necessary support and guidance.

\section{REFERENCES}

[1] D.B. Tembhare, "Modern Entomology" 2015 edition, Himalaya publishing house Pvt. Ltd. Mumbai, 1-2, 1997.

[2] C.C. Labandeira, J.J Sepkoski, Jr., "Insect diversity in fossil record”. Science, New series, Vol. 261, No. 5119, $310,1993$.

[3] C. Gillot, "Entomology", Springer science and business media, 47, 2005.

[4] G. W. Gibbs, "The Role of. Insects in Natural Terrestrial Ecosystems", The New Zealand Entomologist, 1976, Vol. 6 No. $2,113,1976$.

[5] R.U. Aziz, S. Gaherwal, "Egg parasitism caused by Trichogramma spp. against maize stem borer, Chilo partellus", International Journal of Scientific Research in Biological Sciences, Vol.4, Issue.5, pp.14-17, 2017.

[6] M.A. Paray, S.H. Parey, Y. Munazah, K. Rizwana, B.H. Bhat, G. Saurav, S.A. Rather, "The pollinators of apple orchards of Kashmir valley (India) (distributional diversity)". Ecology Environment \& Conservation, 20 (Suppl.): 2014; S471, S475, 2014.

[7] Z. A. Malik, T. Choure, "Economics of Apple Cultivation with Special Reference to South Kashmir - India" Journal of Economics and Sustainable Development, Vol.5, No.9:125-126, 2014.

[8] R.T. Islam, S. Shrivastava, "A Study on Area, Production and Productivity of Apples in J\&K from 2006-07 to 2015-16”, IJSRM Volume 5 Issue, 6516, 2017. 
[9] A. A. Dar, "Growth in Production and Productivity of Horticultural Fruits in Jammu And Kashmir" International Journal of Innovative Research and Advanced Studies (IJIRAS) Volume 4 Issue 21, 2017.

[10] J.S. Shoemaker, B.J.E. Teskey, “Tree Fruit Production”, John Wiley \& Sons, 1-129, 1959.

[12] T.A. Bhat, "Economic of Apple Industry:A Primary Survey in District Shopian Kashmir (India)". Research on Humanities and Social Sciences. Vol.4, No.10, 32, 2014.

[13] D.P. Abrol, "Insect pollination and crop production in Jammu and Kashmir". Current Science Vol. 65, No. 3, Special issue: Pollination Biology in Tropics (10 August 1993), 265, 1993.

[14] J.W. Thomas, J.M. Holland, D. Goulson, "Pollinator-friendly management does not increase the diversity of farmland bees and wasps", Biological Conservation 187,120-121, 2015.

[15] C.K. Sprengel, "The Secret of Nature in the Form and Fertilization of Flowers Discovered", 4 Sets (in German), 1793.

[16] Anonymous, "Mutualism: Lecture 11 Outline", Entomology BIOL 4731, 2003.

[17] M. Faheem, M. Aslam, M. Razaq, "Pollination ecology with special reference to insects- A review" Journal of Research (Science), Vol.15, No.4, 395-409, 2004.

[18] J. R. Mitchell, E. I. Rebecca, J. F. Rebecca, D. K. Jeffrey, Ecology and evolution of plant-pollinator interactions, Annals of Botany, 103:13551356, 2009.

[19] S.A. Dar, Z.H. Khan, A.A. Khan, S.B. Ahmad, "Pollinator Biodiversity and their Conservation", Animal Diversity, Natural History and Conservation Vol. 1, 354-355, 361-362, 2011.

[20] J. Ollerton, R. Winfree, Tarrant, "How many flowering plants are pollinated by animals?” Nordic Society Oikos, 120, 321-322, 2011.

[21] A.M. Klein, B.E. Vaissière, I.S. Cane, Dewenter, S.A. Cunningham, C. Kremen, T. scharntke, "Importance of pollinators in changing landscapes for world crops'. Proc. R. Soc. B (2007) 274, 303-304, 2007.

[22] S.L. Buchmann, G.P. Nabhan, The pollination crisis "The plight of the honey bee and the decline of other pollinators imperils future harvests". The sciences' July/August 1996, 22-27, 1996.

[23] M.S. Percival, "Types of nectar in Angiosperms", New Phytologist 60 (3), 243, 1961.

[24] P.G. Kevan, H.G. Baker, "Insects as flower visitors and pollinators", Ann. Rev. Entomol. 28,407- 453, 1983.

[25] R.G.H. Downer, "Functional role of lipids in insects", In: M. Rockstein (Ed.), Biochemistry of Insects, Academic, New York/ London, 58-92, 1978.

[26] H.G. Baker, I. Baker, "The predictive value of nectar chemistry to the recognition of pollinator types" Israel journal of botany. Vol 39, 1990, $157-158,1990$

[27] R.E. Mallinger, C. Gratton, "Species richness of wild bees, but not the use of managed honeybees, increases fruit set of a pollinator-dependent crop", Journal of Applied Ecology, 52, 323-324, 2015.

[28] M.A. Bashir, S. Saeed, A. Sajjad, K.A. Khan, H.A. Ghramh, M.A. Shehzad, H. Mubarak, N. Mirza, S. Mahpara, M.I.A. Rehmani, M.J. Ansari, "Insect pollinator diversity in four forested ecosystems of southern Punjab, Pakistan", Saudi Journal of Biological Sciences: 1-2, 2018.

[29] O.M. Morris, "Studies in Apple Pollination", Wash. Agr. Expt. Sta. Bul. 163,19, 1921.

[30] R. Javid, G. H. Rather, R. B. Tawseef, A. B. Jahangeer, T. A. Mohammed, S. Rahila, “Effect of Different Crab Apples as Pollinizers on Fruit Quality of Apple under Kashmir Conditions, India", International Journal of Current Microbiology and Applied Sciences ISSN: 2319-7706 Volume 6 Number 12, 2467-2468, 2017.

[31] T. Mushtaq, "Pollinator Diversity and Impact of Pollinators on Quality and Productivity of Apple (Malus domestica Borkh)". Thesis Submitted to The Faculty of Postgraduate Studies Sher-e-Kashmir University of Agricultural Sciences \& Technology of Kashmir, 21-60, 2013.

[32] M. A. Ganie, K. P. Amit, A. Nazeer, "Assessment of relative abundance and diversity of native insect pollinators in apple orchards of Kashmir Himalaya". Asian J Agri Biol, 2(1): 36-37, 2014.

[33] I. Bartomeus, S.G. Potts, I.S. Dewenter, B.E. Vaissi`ere, M. Woyciechowski, K.M. Krewenka, T. Tscheulin, S.P.M. Roberts, H. Szentgy"orgyi, C. Westphal, R. Bommarco, “Contribution of insect pollinators to crop yield and quality varies with agricultural intensification", PeerJ 2:e328; DOI 10.7717/peerj.328,1-2, 2014.

[34] W. H. Brittain, “Apple pollination studies in the Annapolis valley” N.S., Canada, Canada Department Agriculture Bul. 162, n.s., 92-93, 1933.

[35] S.E. McGregor, "Insect Pollination of Cultivated Crop Plants", United States Department of Agriculture (USDA), Chapter 5: Tree Fruits \& Nuts and Exotic Tree Fruits \& Nuts, APPLE, 1-12, 1976.

[36] M. A. Ganie, K. P. Amit, A. Nazeer, "Native Insect Pollinators in Apple Orchards under different management practices in the Kashmir Valley", Turkish Journal of Agriculture- Food Science and Technology, 1(1): 34-35, 2013.

[37] F. Akhter, A.L. Khanday, S.T. Ahmad, "Pollination potential: A comparative study of various hymenopteran insects pollinating some economically important crops in Kashmir”, Int. J. Adv. Res. Biol. Sci. 2016. 3(9):50, 2016.

[38] A.O. Katherine, I.P. Vaughan, Jane Memmott, "The forgotten flies: the importance of non-syrphid Diptera as pollinators". Proc. R. Soc. B 282, $1,2015$.

[39] M. P. D. Garratt, T. D. Breeze, V. Boreux, M. T. Fountain, M. McKerchar, S.M. Webber, D. J. Coston1, N. Jenner, R. Dean, D. B. Westbury, J. C. Biesmeijer, S.G. Potts, "Apple Pollination: Demand Depends on Variety and Supply Depends on Pollinator Identity". PLOS ONE | DOI: $10.1371,1-2,2016$.

[40] I. Slathia, N. K. Tripath, "Impact of Climate Change on Honey-Bee Populations and Diseases". Bio Bulletin 2(1), 40-42, 2016.

[41] A. Q. Rather, A. H. Shah, "Consequences of pesticide pollution upon the population of Collembola (springtails) in Kashmir apple orchard edaphic ecosystem". J. Ecophysiol. Occup. HIth. 10(2010), 9-11, 2010. 